\title{
Angiogenesis in Peritoneal Dialysis
}

\author{
A.W.D. Stavenuiter ${ }^{a}$ M.N. Schilte ${ }^{a} \quad$ P.M. Ter Wee ${ }^{b} \quad$ R.H.J. Beelen ${ }^{a}$ \\ Departments of a Molecular Cell Biology and Immunology, and bephrology, VU University Medical Center, \\ Amsterdam, The Netherlands
}

\section{Key Words}

Peritoneal dialysis • Angiogenesis • Ultrafiltration capacity

\begin{abstract}
Long-term exposure to peritoneal dialysis fluid induces morphological alterations, including angiogenesis, leading to a loss of ultrafiltration (UF) capacity. We discuss the effect of different factors in peritoneal dialysis (PD) on angiogenesis. In addition, we describe the process of angiogenesis and the possible role of different cell types in the peritoneum upon PD contributing to new blood vessel formation. Furthermore, we review several interventions used in our rat PD exposure model to decrease angiogenesis in PD. Moreover, we show new data on the use of sunitinib to inhibit angiogenesis in this rat model. Although various interventions seem to be promising, well-randomised clinical trials showing absolute prevention of angiogenesis and UF failure are, yet, still missing. To make real progress in PD treatment, the aim should be to prevent angiogenesis as well as peritoneal fibrosis and PD-induced inflammation.
\end{abstract}

Copyright ๑ 2011 S. Karger AG, Basel

\section{Introduction}

Peritoneal dialysis (PD) has been a kidney replacement therapy for end-stage renal disease for approximately 30 years [1]. In PD, the ability of the peritoneal membrane to function as a semi-permeable membrane is exploited to allow diffusive exclusion of uraemic toxins and exchange of solutes between the circulation and the PD fluid (PDF) $[2,3]$. Currently, in Europe approximately $10 \%$ of the dialysis patients are using PD [4]. Advantages of PD include a more continuous removal of waste products, which results in an improved well-being of the PD patients, when compared to haemodialysis where the waste products accumulate in between dialysis. In addition, PD patients show increased mobility compared to haemodialysis patients, and PD is less expensive. Major disadvantages are the risk of PD-induced peritonitis and peritoneal tissue remodelling and angiogenesis, which can lead to technique failure.

Daily instillation of PDF causes morphological and functional alterations of the peritoneal membrane. Changes observed after PD are detachment of the mesothelial layer, increased submesothelial extracellular matrix (ECM) deposition, fibrosis, and angiogenesis (fig. 1). The changes arising due to PD ultimately lead to ultrafiltration (UF) failure (UFF) [5]. In this review, the focus will be on new blood vessel formation upon PD.

The peritoneal membrane consists of three layers, namely a mesothelial monolayer which covers the submesothelial compact zone - comprising connective tissue, $\mathrm{ECM}$, a few fibroblasts, immune cells as macrophages and mast cells - and a third deeper loose adipose layer in which peritoneal capillaries and peritoneal lymphatic vessels are found [6-8].

\section{KARGER}

Fax +4161306 1234

E-Mail karger@karger.ch

www.karger.com
(C) 2011 S. Karger AG, Basel

$1420-4096 / 11 / 0344-0245 \$ 38.00 / 0$

Accessible online at:

www.karger.com/kbr
A.W.D. Stavenuiter

Department of Molecular Cell Biology and Immunology

VU University Medical Center, Room MF J289, PO Box 7057

NL-1007 MB Amsterdam (The Netherlands)

Tel. +31 20444 8079, E-mail a.stavenuiter@vumc.nl 
Fig. 1. Histological changes after longterm PD treatment. Toluidine blue staining of the omentum showing induction of milky spots and angiogenesis in a PDtreated rat (b) and a control rat (a). Staining of the mesentery showing blood vessel formation (CD31, red) and macrophage influx (ED2, green) in a PD-treated rat (d) and a control rat (c). Adapted from Schilte et al. [59]. For colours see online version.
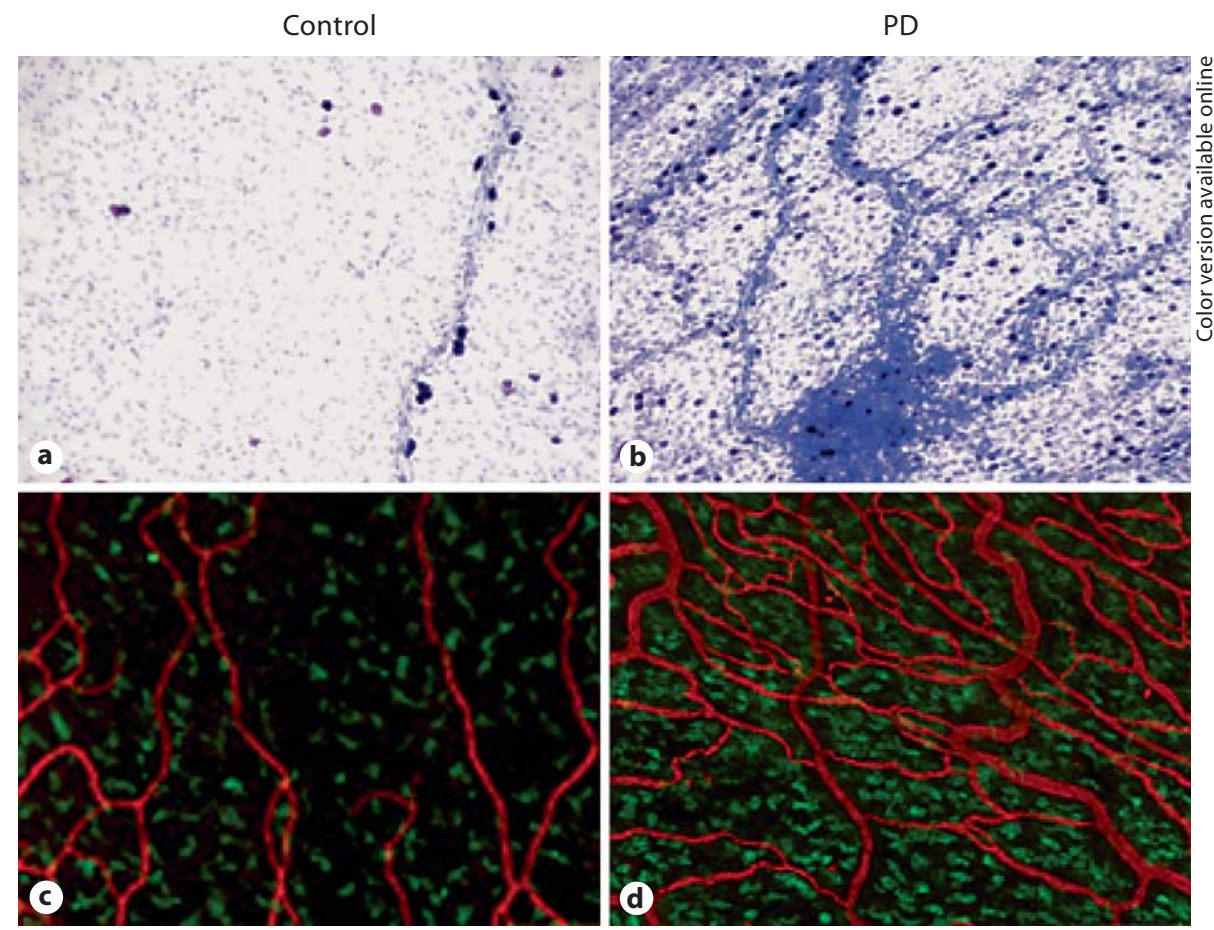

The mesenteric and celiac arteries provide the visceral peritoneum with blood. Peritoneal microvessels exchange oxygen, hormones, water, nutrients, antibodies and inflammatory mediators in the peritoneal membrane and cavity [2].

Angiogenesis results in an increased effective surface area exchange whereas lymphangiogenesis leads to raised lymphatic absorption rates. The expanded vascular network results in a decrease in the glucose-driven osmotic pressure of the PDF leading to UF loss. In addition, vascular wall changes such as thickening and increased permeability cause an increase in small solute transport and thus in reduction time for exchanging waste products $[9$, 10].

\section{Peritoneal Dialysis Fluids}

PDF is instilled in the peritoneal cavity via a permanent catheter and rat studies have shown a minor increase in vessel density when a rat-o-port was implemented for 5 weeks [11]. Briefly, in our rat PD exposure model the rats undergo surgery whereby a small incision is made in the skin of the abdomen and in the linea alba. A silicon catheter $( \pm 12 \mathrm{~cm})$ attached to a mini vascular access port is tunnelled subcutaneously from the abdominal incision to the neck of the rat. The other end of the catheter is introduced into the peritoneal cavity. In the first week, the animals receive $2 \mathrm{ml}$ of saline with $1 \mathrm{U} / \mathrm{ml}$ heparin. Thereafter, during a 5- to 10-week period, the rats are injected once daily with $10 \mathrm{ml}$ PDF [12].

Under normal conditions, the human peritoneum contains approximately $100 \mathrm{ml}$ of fluid which serves as a lubricating moisture. During continuous ambulatory peritoneal dialysis, around 2 litres of PDF, thus 20 times as much, is instilled with 5 exchanges per day.

Using our rat exposure model, Zareie et al. [13] showed an increase in the number of blood vessels in the omentum, the mesentery and parietal peritoneum upon PD treatment with lactate buffer. Although the blood vessel formation was less in the lactate buffer control in comparison to the glucose containing PDF, this indicates that only the instillation of a large amount of fluid results in angiogenesis but also marks the importance of the composition of the PDF (fig. 2). The effect of different components in $\mathrm{PD}$, including catheter, uraemia, peritonitis, buffer, glucose and glucose degradation products (GDPs), on angiogenesis is summarised in table 1.

Therefore, research has been performed to study the relation between UFF and the composition of the PDF. Conventional $\mathrm{PDF}$ s have a low $\mathrm{pH}$ value, a high glucose concentration in a lactate-buffered solution, and contain 


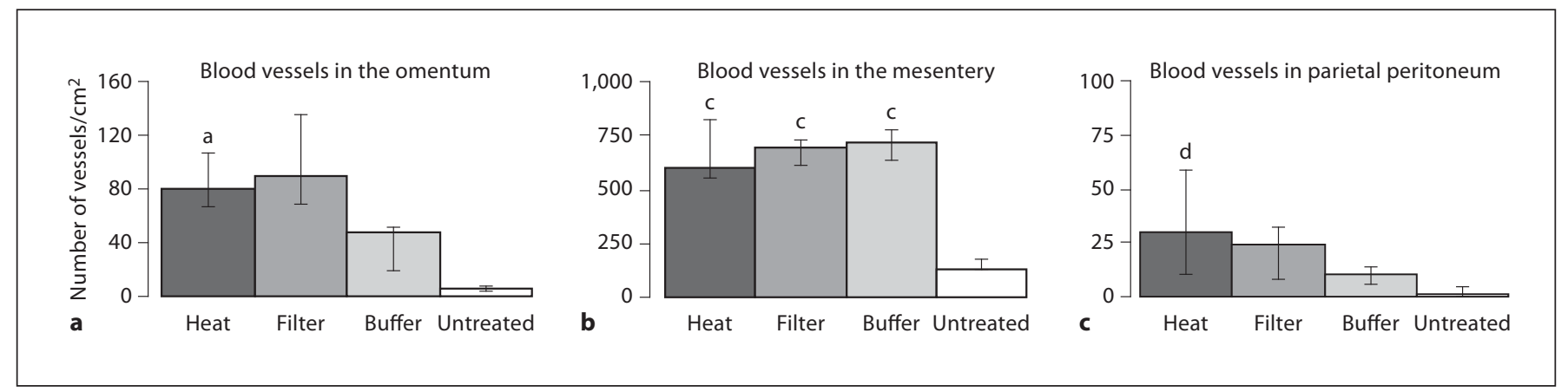

Fig. 2. Blood vessel formation in a rat exposure model upon treatment with different PDFs. The number of blood vessels per $\mathrm{cm}^{2}$ in the omentum (a) and in the mesentery (b) after toluidine blue staining on spread preparations. c The number of blood vessels within the submesothelial ECM after CD31 staining on frozen sections, adapted from Zareie et al. [13]. Experimental groups: heat (dianeal), filter (filter-sterilised lactate-buffered PDF with the same electrolyte composition and $\mathrm{pH}$ as the heat-sterilised solution, and also containing 3.86\% glucose), buffer (lactate buffer with the same electrolyte composition and $\mathrm{pH}$ as the other two solutions but without glucose), untreated. Data are presented as median and interquartile ranges. ${ }^{a}$ Heat versus buffer and untreated: $p<0.04 ;{ }^{b}$ filter versus buffer and untreated: $p<0.002 ;{ }^{c}$ heat, filter and buffer versus untreated: $\mathrm{p}<0.02$; ${ }^{\mathrm{d}}$ heat versus untreated: $\mathrm{p}<0.02$.
Table 1. The effect of different components in $\mathrm{PD}$ on angiogenesis

\begin{tabular}{lllllllll}
\hline & \multicolumn{3}{l}{ Extrinsic factors } & & & \multicolumn{3}{l}{ Fluid characteristics } \\
\cline { 2 - 3 } \cline { 5 - 7 } & catheter uraemia & peritonitis & & $\begin{array}{l}\text { (lactate) } \\
\text { buffer }\end{array}$ & $\begin{array}{l}\text { buffer }+ \\
\text { glucose }\end{array}$ & $\begin{array}{l}\text { buffer+glucose } \\
+ \text { GDPs }\end{array}$ \\
\hline Angiogenesis & + & + & + & & + & ++ & +++ \\
\hline
\end{tabular}

Peritoneal changes are indicated as: $+=$ moderate $++=$ strong; $+++=$ very strong, compared to control rats.
GDPs which are formed during heat sterilization of the fluids. In vitro studies indicate impairment of the host defence mechanism due to the bioincompatibility of PDFs [14]. More physiological PDF bicarbonate and bicarbonate/lactate-buffered PDF with a physiological $\mathrm{pH}$ value and less GDPs have been developed. Evidence has been found that supports the benefit of switching from conventional to bicarbonate/lactate-buffered PDFs [15, 16]. Hekking et al. [15] compared a bicarbonate/lactatebuffered PDF (Physioneal) with a lactate-buffered PDF (Dianeal) in a rat PDF instillation model. Reduced neovascularisation and fibrosis was observed after 9-10 weeks of bicarbonate/lactate-buffered PDF compared to the lactate-buffered PDF-treated group.

Moreover, a comparable rat study showed a higher vascular density and more progressive fibrosis, associated with an upregulation of transforming growth factor $\beta$
(TGF- $\beta$ ) and vascular endothelial growth factor (VEGF), in the group treated with conventional dianeal versus the bicarbonate/lactate-buffered physioneal-treated group. In addition, the dianeal group showed higher accumulation levels of advanced glycation end products (AGEs) [16]. Biopsy specimens from continuous ambulatory peritoneal dialysis patients show AGE accumulation in the interstitium and in the microvessels, which was correlated with progression of interstitial fibrosis and vascular sclerosis and showed an inverse relationship with UFF [17]. AGEs can upregulate TGF- $\beta$ and VEGF expression $[18,19]$. Besides, AGEs have been found to be a chemoattractant for monocytes. In addition, monocytes cultured on a matrix composed of collagen IV mixed with AGEalbumin have been found to produce platelet-derived growth factor, a mitogen for vascular smooth muscle cells [20]. 
Patient studies also show a correlation between time on glucose PD, increased VEGF production and UFF. When the patients changed to glucose-free PDF, the levels of VEGF dropped, which indicates a role of high glucose concentration in the induction of VEGF production [21].

\section{Vascular Endothelial-Specific Growth Factors}

VEGFs are key players in angiogenesis and, as mentioned before, also in peritoneal angiogenesis. Vessel formation is a multistep process. It begins with vasculogenesis, a stage in which endothelial cells (ECs) differentiate and proliferate in an area without any vascular tissue followed by the formation of a primitive tubular network. Angiogenic remodelling takes place where the vessels enlarge and mature. ECs interact with the supporting cells and the surrounding matrix. Sprouting of vessels can also occur. In this process, mature vessels destabilise first after which new vessels are formed.

Besides VEGFs, which are important in the initiation of the formation of immature vessels, also other vascular endothelial-specific growth factors including 4 members of the angiopoietin (Ang) family and at least 1 of the ephrin (Eph) family are necessary for appropriate angiogenesis. Ang1, a Tie2 ligand, is needed for vessel stabilisation, integration with supporting cells, and maturation. Ang2 is involved in destabilisation of the vessels $[22,23]$. Reduction in Tie2, an Ang receptor, and increased levels of Ang2 in a uraemic rat PD model have been shown to correlate with peritoneal angiogenesis [23]. It is speculated that EphB2 and EphB4 are important in the venous versus arterial identity and EphB2 is important in the maintenance of interaction between endothelial and smooth muscle cells. To our knowledge, there is no direct link between Ephs and angiogenesis in PD; however, in some tumours, the endothelium of newly formed vessels highly expresses EphB2 [22].

\section{Peritoneal Cells Involved in PD-Induced Angiogenesis}

Angiogenesis is not simply regulated by one mechanistic switch. A lot of factors are involved in the formation of new blood vessels. These factors are produced by many different cells. Briefly, some important cells and their potential role in angiogenesis will be described.
The predominant cell type in the human and rat peritoneal cavity are the macrophages $[24,25]$. Macrophages, together with polymorphonuclear leucocytes, are the first-line defence against invading micro-organisms during PD. Activated macrophages release prostaglandin $\mathrm{E}_{2}$, interleukin (IL)-1 $\beta$, IL-6, IL-8, monocyte chemotactic protein-1 (MCP-1) and tumour necrosis factor $\alpha$ (TNF- $\alpha$ ). Prostaglandin $\mathrm{E}_{2}$ is involved in angiogenesis by enhancing endothelial cell migration and contributing to cell survival [26]. MCP-1 not only attracts other monocytes from the blood but has also been shown to be directly involved in angiogenesis. In vitro experiments show an enhanced MCP-1-induced protein expression by human umbilical vein ECs upon MCP-1 stimulation. MCP-1-induced protein in turn enhances endothelial cell apoptosis, proliferation, migration, and the induction of other angiogenesisrelated genes resulting in capillary-like tube formation [27]. In vivo, it has been demonstrated that overexpression of IL-1 $\beta$ leads to a sustained angiogenesis and submesothelial thickening and fibrosis [28]. In addition, IL-1 $\beta$ increases vessel-like structures, through enhancing VEGF production and downregulation of Ang1, and augments proliferation when added to ECs $[29,30]$. Also, IL- 6 and IL- 8 can be involved in angiogenesis since IL- 6 stimulates endothelial progenitor cell proliferation, migration and Matrigel tube formation and IL-8 enhances EC survival, proliferation and capillary tube formation [31, 32]. Macrophage-produced TNF- $\alpha$ causes induction of capillarylike blood vessel formation both in vitro and in vivo [33].

In healthy peritoneum, mast cells are present and the number of mast cells increases upon infection [34, 35]. Activated mast cells can induce new vessel formation by producing proangiogenic factors like TGF- $\beta$, basic fibroblast growth factor, VEGF, TNF- $\alpha$ and IL-8 (see above) $[36,37]$. In addition, mast cells are capable of producing tryptase, stimulating vascular tube formation, and chymase $[38,39]$. Although the relative number of peritoneal mast cells in the PDF of rat PD exposure models declines, mast cells are strongly associated with PD-induced angiogenesis. This is probably due to mast cell accumulation in the omentum [40]. The mast cells are found near blood vessels and the number of mast cells in the omentum strongly correlates with the number of blood vessels. PDF exposure in mast cell-depleted wild-type rats and mast cell-deficient $W s / W s$ rats shows a significant reduction in omental angiogenesis also indicating a compelling role for mast cells in PD-induced angiogenesis [41].

ECs are very important cells in PD because of their prominent role to create a barrier for solute transport during PD. Upon PD, ECs of the vessels in milky spots of 
PD-treated animals change in morphology. The ECs enlarge and become activated [15]. Activation of ECs, for example by surgery in the abdomen, induces IL- 6 and MCP-1 production, which leads to the attraction of immune cells but also supports angiogenesis [42].

One of the adverse effects in PD is the loss of mesothelial cells (MCs); nevertheless, MCs have an important role in new vessel formation. The remaining MCs become activated [43]. Basic fibroblast growth factor, heparin-binding epidermal growth factor and VEGF mRNA is constitutively expressed by resting MCs in vitro. These growth factors are known to be involved in angiogenesis and vascular permeability $[44,45]$. In culture, MCs upregulate VEGF expression upon stimulation with TNF- $\alpha$, IL-1 $\beta$ or GDPs $[46,47]$. GPDs also increase VEGF production by ECs [47]. In addition, human MCs can produce the chemokines IL- 8 , huGRO- $\alpha, \gamma$ IP-10, RANTES and MCP1 , which either stimulate angiogenesis directly or might enhance vascularisation via attracting macrophages to the peritoneal cavity [48].

So, a number of pro-angiogenic factors have been shown in association with high peritoneal solute transport rates [49]. However, not only direct pro-angiogenic factors produced by the cells described above cause an increase in vessel formation, also other mediators in PD can influence the vascularisation. Important is also the epithelial-to-mesenchymal transition (EMT), under the influence of TGF- $\beta$. During EMT, MCs lose their epithelial phenotype and acquire myofibroblast-like characteristics. MCs that had undergone EMT augmented the ability to invade and migrate into the submesothelial layer. Besides the change in morphological features, the non-epithelioid MCs produce higher amounts of VEGF than the non-EMT MC counterparts. In PD patients, a correlation has been found between the overexpression of VEGF by non-epithelioid MCs and high transport rates [50]. Moreover, damaged MCs also lead to peritoneal fibrosis due to the secretion of ECM macromolecules consisting of collagen, fibronectin, laminin, proteoglycans and amongst others the production of TGF$\beta_{1}$. TGF- $\beta_{1}$ has a kind of positive feedback loop and enhances the production of ECM leading to further new vessel formation [51].

\section{Prevention of PD-Induced Angiogenesis}

Over the last few years, research has focused on the prevention of UFF and peritoneal membrane changes during PD treatment. The use of angiogenesis inhibitors may lead to reduced vessel formation resulting in sustained UF and improved well-being of the patients due to a more continuous removal of waste products. Several studies have been performed to reduce angiogenesis in PD.

Cyclooxygenase (COX) enzymes are involved in prostaglandin synthesis. COX-2 is known to be an angiogenesis stimulator by upregulating the mRNA transcription and the production of VEGF. Furthermore, it enhances the production of thromboxane $A_{2}$, prostaglandin $E_{2}$ and prostacyclin. Studies have shown a possible role for COX-2 inhibitors in the reduction in fibrosis and angiogenesis both in vitro and in vivo, although data are contradictory in some experiments [52, 53]. Fabbrini et al. [54] have shown the influence of the COX-2 inhibitor, celecoxib, in PD in a rat exposure model. Celecoxib treatment prevented $\mathrm{PD}$-induced angiogenesis in both the omentum and parietal peritoneum. New lymphatic vessel formation was totally prohibited. Although the prostaglandin $\mathrm{E}_{2}$ levels were reduced, VEGF levels were unaffected by celecoxib treatment. Most importantly, UF was restored upon celecoxib treatment. Celecoxib may therefore be of interest in the prevention of UF in PD patients; however, cardiovascular safety must be taken into account.

Another interesting possibility to prevent angiogenesis is the use of tyrosine kinase inhibitors. Sunitinib is a tyrosine kinase inhibitor and involved in the inhibition of VEGF and platelet-derived growth factor receptor signalling. A case study performed by Tapiawala et al. [55] showed a positive effect of a PD patient treated with sunitinib against metastatic renal cell carcinoma. The patient's peritoneal permeability remained stable even over 10 years. Our animal studies show prevention of new vessel formation in the omentum as well as the mesentery by sunitinib after 5 weeks of PD treatment (fig. 3). However, sunitinib treatment further increased the PD-induced VEGF levels. This has also been published by others and could be explained by a lack of degradation due to blocking of the VEGF receptor signalling [55, 56]. Interestingly, a loss of mast cells in the mesentery was observed in the sunitinib-treated animals.

Together with previous studies, in which mast-cell-deficient rats also showed significantly reduced angiogenesis in the omentum and in which strong correlations between omental angiogenesis and mast cells have been found, this suggests an important role for mast cells in new blood vessel formation upon PD [41].

There are not only studies on the effect of direct angiogenesis inhibitors in PD but also on the prevention of the onset of angiogenesis. For example, Sandoval et al. 

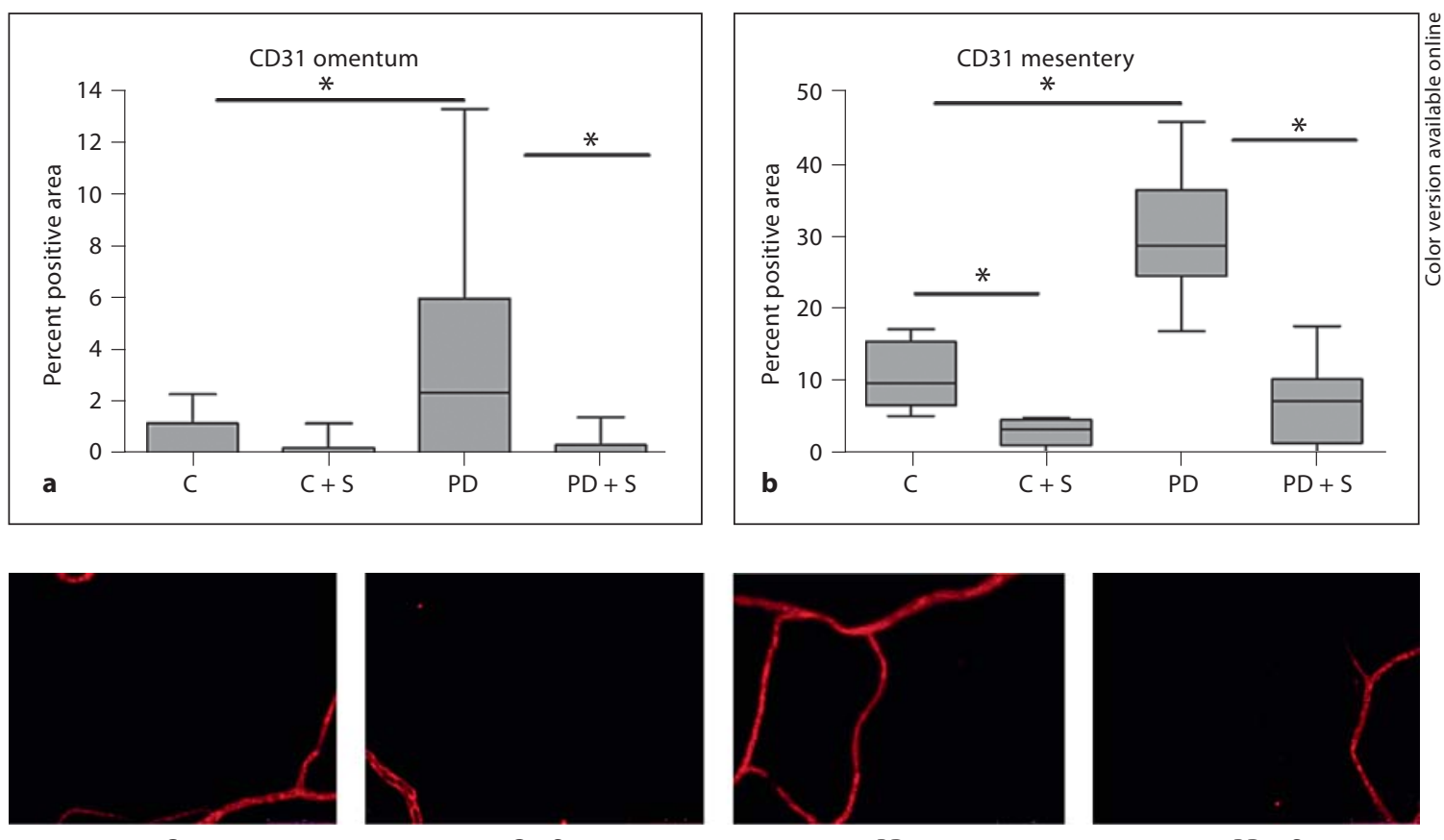

C

$\mathrm{C}+\mathrm{S}$

PD

$\mathrm{PD}+\mathrm{S}$
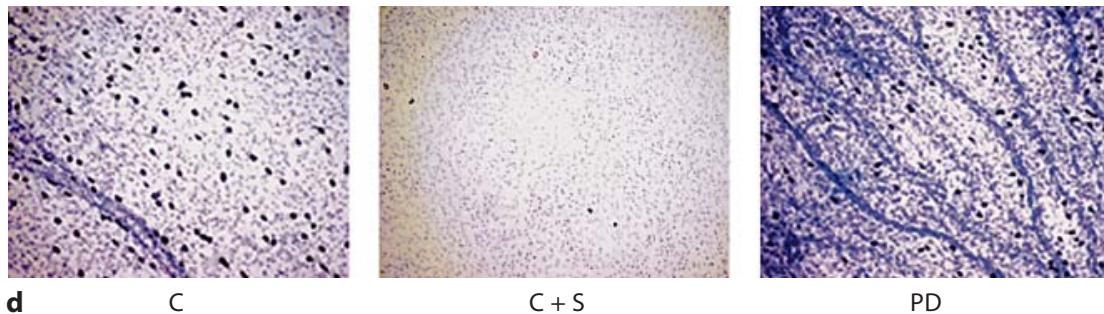

PD

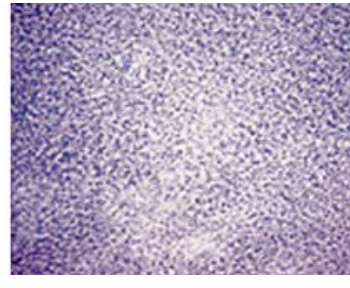

$\mathrm{PD}+\mathrm{S}$

Fig. 3. Prevention of angiogenesis by sunitinib treatment. Percentage of vessel surface area in the omentum $\left(\mathbf{a} ;{ }^{*} \mathrm{p}<0.01\right)$ and mesentery $\left(\mathbf{b} ;{ }^{*} \mathrm{p}<0.05\right)$ measured by CD31. Box plots indicate the median and 5-95\% level. Representative examples of CD31 stain- ing of the omentum (c). Toluidine blue staining of the mesentery confirms CD31 measurements (d). Magnifications $\times 10$. C $=$ Control; $\mathrm{C}+\mathrm{S}=$ control + sunitinib; $\mathrm{PD}+\mathrm{S}=\mathrm{PD}+$ sunitinib. For colours see online version.
[57] investigated the administration of rosiglitazone, a peroxisome proliferator-activated receptor- $\gamma$ agonist, in a mice exposure model. Peroxisome proliferator-activated receptor $\gamma$ agonists are known to control glycaemia by improved insulin sensitivity and have anti-inflammatory, and therefore probably also antifibrotic, properties. Administration of the drug led to reduced AGE formation and inflammation, a preserved mesothelial cell layer, and improved UF compared to the PD control mice. However, although promising for inhibiting the alterations due to PD, rosiglitazone treatment of patients with type II diabetes has been linked to several severe side effects as shown in a meta-analysis study by Singh et al. [58].
Since EMT also leads to angiogenesis, there has also been a focus on the prevention of EMT upon PD. Loureiro et al. [24] studied the effects of bone morphogenic protein-7, which antagonises TGF- $\beta_{1}$ and can promote mesenchymal-to-epithelial transition. Inhibition of bone morphogenic protein-7 in a rat PD exposure model inhibited angiogenesis as well as the number of cytokeratin-positive cells, indicating a positive correlation between EMT and angiogenesis.

Whether these positive interventions used in animal studies can be translated into clinical medicine remains to be elucidated. Currently, the COX-2 inhibitor celecox$\mathrm{ib}$ is under study in a clinical trial. 


\section{Conclusion}

PD has improved over the years, for example by the use of new PDF; however, further research on the prevention of the alterations of the peritoneum upon PD is necessary. Although some interventions are promising, well-randomised clinical trials showing complete reduction in angiogenesis and UFF are lacking. To improve PD treatment, research should not only focus on the prevention of angiogenesis but on a combination of angiogenesis, peritoneal fibrosis, as well as PD-induced inflammation. This will ultimately result in future PD treatment regimens with new inhibitory drugs without undesirable side effects.

\section{Acknowledgement}

This work was supported by the Dutch Kidney Foundation, grant No. C05-2142 and C09-2331.

\section{References}

1 Palmer RA: As it was in the beginning: a history of peritoneal dialysis. Perit Dial Int 1982;2:16-22.

2 Rippe B, Rosengren BI, Venturoli D: The peritoneal microcirculation in peritoneal dialysis. Microcirculation 2001;8:303-320.

3 Krediet RT, Lindholm B, Rippe B: Pathophysiology of peritoneal membrane failure. Perit Dial Int 2000;20(suppl 4):S22-S42.

4 ERA-EDTA. ERA-EDTA Registry Annual Report 2008. 2010. Ref Type: Report.

$\checkmark 5$ Williams JD, Craig KJ, Topley N, Von Ruhland C, Fallon M, Newman GR, Mackenzie RK, Williams GT: Morphologic changes in the peritoneal membrane of patients with renal disease. J Am Soc Nephrol 2002;13:470479.

6 Digenis GE: Anatomy of the Peritoneal Membrane. Perit Dial Bull 1984;4:63-69.

$\rightarrow 7$ Nagy JA: Peritoneal membrane morphology $>_{16}$ and function. Kidney Int 1996;50:S2-S11.

$\checkmark 8$ Nessim SJ, Perl J, Bargman JM: The reninangiotensin-aldosterone system in peritoneal dialysis: is what is good for the kidney also good for the peritoneum? Kidney Int 2010; 78:23-28.

9 Michels WM, Zweers MM, Smit W, Korevaar J, Struijk DG, van Westrhenen R, Krediet RT: Does lymphatic absorption change with the duration of peritoneal dialysis? Perit Dial Int 2004;24:347-352.

10 Lai KN, Tang SC, Leung JC: Mediators of inflammation and fibrosis. Perit Dial Int 2007; 27(suppl 2):S65-S71.

- 11 Zareie M, van Lambalgen AA, De Vriese AS, Van Gelderop E, Lameire N, ter Wee PM, Beelen RH, van den Born J, Tangelder GJ: Increased leukocyte rolling in newly formed mesenteric vessels in the rat during peritoneal dialysis. Perit Dial Int 2002;22:655-662.

-12 Hekking LH, Aalders MC, van Gelderop E, Zweers MM, Struijk DG, Havenith CE, Beelen RH: Effect of peritoneal dialysis fluid measured in vivo in a rat-model of continuous peritoneal dialysis. Adv Perit Dial 1998; 14:14-18.
13 Zareie M, Hekking LH, Welten AG, 20 Kirstein M, Brett J, Radoff S, Ogawa S, Stern Driesprong BA, Schadee-Eestermans IL, Faict D, Leyssens A, Schalkwijk CG, Beelen $\mathrm{RH}$, ter Wee PM, van den Born J: Contribution of lactate buffer, glucose and glucose degradation products to peritoneal injury in vivo. Nephrol Dial Transplant 2003;18:2629-2637. 14 Calame W, Hendrickx RJBM, Namavar F, Oe LP, Beelen RHJ: Effect of glucose in dialysis fluid on antibacterial defense in the peritoneal cavity. Infect 1995;30:227-233.

15 Hekking LH, Zareie M, Driesprong BA, Faict D, Welten AG, de G, I, Schadee-Eestermans IL, Havenith CE, van den Born J, ter Wee PM, Beelen RH: Better preservation of peritoneal morphologic features and defense in rats after long-term exposure to a bicarbonate/lactate-buffered solution. J Am Soc Nephrol 2001;12:2775-2786.

6 Mortier S, Faict D, Lameire NH, De Vriese AS: Benefits of switching from a conventional to a low-GDP bicarbonate/lactate-buffered dialysis solution in a rat model. Kidney Int 2005;67:1559-1565.

17 Honda K, Nitta K, Horita S, Yumura W, Nihei H, Nagai R, Ikeda K, Horiuchi S: Accumulation of advanced glycation end products in the peritoneal vasculature of continuous ambulatory peritoneal dialysis patients with low ultra-filtration. Nephrol Dial Transplant 1999; 14:1541-1549.

18 Yamagishi S, Yonekura H, Yamamoto Y, Katsuno K, Sato F, Mita I, Ooka H, Satozawa N, Kawakami T, Nomura M, Yamamoto H: Advanced glycation end products-driven angiogenesis in vitro. J Biol Chem 1997;272: 8723-8730.

19 De Vriese AS, Flyvbjerg A, Mortier S, Tilton RG, Lameire NH: Inhibition of the interaction of AGE-RAGE prevents hyperglycemiainduced fibrosis of the peritoneal membrane. J Am Soc Nephrol 2003;14:2109-2118.
D, Vlassara H: Advanced protein glycosylation induces transendothelial human monocyte chemotaxis and secretion of platelet-derived growth-factor - role in vasculardisease of diabetes and aging. Proc Natl Acad Sci USA 1990;87:9010-9014.

21 Zweers MM, Struijk DG, Smit W, Krediet RT: Vascular endothelial growth factor in peritoneal dialysis: a longitudinal follow-up. J Lab Clin Med 2001;137:125-132.

22 Yancopoulos GD, Davis S, Gale NW, Rudge JS, Wiegand SJ, Holash J: Vascular-specific growth factors and blood vessel formation. Nature 2000;407:242-248.

23 Yuan JZ, Fang W, Ni ZH, Dai HL, Lin AW, Cao LO, Qian JQ: Peritoneal morphologic changes in a peritoneal dialysis rat model correlate with angiopoietin/Tie-2. Pediatr Nephrol 2009;24:163-170.

24 Loureiro J, Schilte M, Aguilera A, Albar-Vizcaino P, Ramirez-Huesca M, Perez-Lozano ML, Gonzalez-Mateo G, Aroeira LS, Selgas R, Mendoza L, Ortiz A, Ruiz-Ortega M, van den BJ, Beelen RH, Lopez-Cabrera M: BMP7 blocks mesenchymal conversion of mesothelial cells and prevents peritoneal damage induced by dialysis fluid exposure. Nephrol Dial Transplant 2010;25:1098-1108.

-25 Bos HJ, van Bronswijk H, Helmerhorst TJ, Oe PL, Hoefsmit EC, Beelen RH: Distinct subpopulations of elicited human macrophages in peritoneal dialysis patients and women undergoing laparoscopy: a study on peroxidatic activity. J Leukoc Biol 1988;43:172-178.

26 Kamiyama M, Pozzi A, Yang L, Debusk LM, Breyer RM, Lin PC: EP2, a receptor for PGE(2), regulates tumor angiogenesis through direct effects on endothelial cell motility and survival. Oncogene 2006;25: 7019-7028.

27 Niu J, Azfer A, Zhelyabovska O, Fatma S, Kolattukudy PE: Monocyte chemotactic protein (MCP)-1 promotes angiogenesis via a novel transcription factor, MCP-1-induced protein (MCPIP). J Biol Chem 2008;283: 14542-14551. 
28 Margetts PJ, Kolb M, Yu L, Hoff CM, Holmes CJ, Anthony DC, Gauldie J: Inflammatory cytokines, angiogenesis, and fibrosis in the rat peritoneum. Am J Pathol 2002;160: 2285-2294.

29 Rosell A, Arai K, Lok J, He TR, Guo SZ, Navarro M, Montaner J, Katusic ZS, Lo EH: Interleukin-1 beta augments angiogenic responses of murine endothelial progenitor cells in vitro. J Cereb Blood Flow Metab 2009;29:933-943.

-30 Fan F, Stoeltzing O, Liu WB, McCarty MF, Jung YD, Reinmuth N, Ellis LM: Interleukin-1 beta regulates angiopoietin-1 expression in human endothelial cells. Cancer Res 2004;64:3186-3190.

- 31 Fan Y, Ye J, Shen F, Zhu Y, Yeghiazarians Y, Zhu W, Chen Y, Lawton MT, Young WL, Yang GY: Interleukin-6 stimulates circulating blood-derived endothelial progenitor cell angiogenesis in vitro. J Cereb Blood Flow Metab 2008;28:90-98.

- 32 Li A, Dubey S, Varney ML, Dave BJ, Singh RK: IL-8 directly enhanced endothelial cell survival, proliferation, and matrix metalloproteinases production and regulated angiogenesis. J Immunol 2003;170:3369-3376.

- 33 Leibovich SJ, Polverini PJ, Shepard HM, Wiseman DM, Shively V, Nuseir N: Macrophage-induced angiogenesis is mediated by tumour necrosis factor-alpha. Nature 1987; 329:630-632.

- 34 Jimenez-Heffernan JA, Bajo MA, Perna C, Del PG, Larrubia JR, Gamallo C, SanchezTomero JA, Lopez-Cabrera M, Selgas R: Mast cell quantification in normal peritoneum and during peritoneal dialysis treatment. Arch Pathol Lab Med 2006;130:11881192.

- 35 Alscher DM, Braun N, Biegger D, Fritz P: Peritoneal mast cells in peritoneal dialysis patients, particularly in encapsulating peritoneal sclerosis patients. Am J Kidney Dis 2007;49:452-461.

36 Norrby K: Mast cells and angiogenesis. APMIS 2002;110:355-371.

- 37 Katsanos GS, Anogeianaki A, Orso C, Tete S, Salini V, Antinolfi PL, Sabatino G: Mast cells and chemokines. J Biol Regul Homeost Agents 2008;22:145-152.

- 38 Blair RJ, Meng H, Marchese MJ, Ren S, Schwartz LB, Tonnesen MG, Gruber BL: Human mast cells stimulate vascular tube formation. Tryptase is a novel, potent angiogenic factor. J Clin Invest 1997;99:26912700.

39 Muramatsu M, Katada J, Hayashi I, Majima M: Chymase as a proangiogenic factor. A possible involvement of chymase-angiotensin-dependent pathway in the hamster sponge angiogenesis model. J Biol Chem 2000;275:5545-5552.
40 Zareie M, Hekking LH, Driesprong BA, ter Wee PM, Beelen RH, van den Born J: Accumulation of omental mast cells during peritoneal dialysis. Perit Dial Int 2001;21(suppl 3):S373-S376.

41 Zareie M, Fabbrini P, Hekking LH, Keuning ED, ter Wee PM, Beelen RH, van den Born J: Novel role for mast cells in omental tissue remodeling and cell recruitment in experimental peritoneal dialysis. J Am Soc Nephrol 2006;17:3447-3457.

42 Riese J, Niedobitek G, Lisner R, Jung A, Hohenberger W, Haupt W: Expression of interleukin-6 and monocyte chemoattractant protein- 1 by peritoneal sub-mesothelial cells during abdominal operations. J Pathol 2004; 202:34-40.

43 Hekking LH, Zweers MM, Keuning ED, Driesprong BA, de Waart DR, Beelen RH, van den Born J: Apparent successful mesothelial cell transplantation hampered by peritoneal activation. Kidney Int 2005;68: 2362-2367.

44 El-Assal ON, Paddock H, Marquez A, Besner GE: Heparin-binding epidermal growth factor-like growth factor gene disruption is associated with delayed intestinal restitution, impaired angiogenesis and poor survival after intestinal ischemia in mice. J Pediatr Surg 2008;43:1182-1190.

-45 Cross MJ, Claesson-Welsh L: FGF and VEGF function in angiogenesis: signalling pathways, biological responses and therapeutic inhibition. Trends Pharmacol Sci 2001;22: 201-207.

46 Jayne DG, Perry SL, Morrison E, Farmery SM, Guillou PJ: Activated mesothelial cells produce heparin-binding growth factors: implications for tumour metastases. Br J Cancer 2000;82:1233-1238.

47 Inagi R, Miyata T, Yamamoto T, Suzuki D, Urakami K, Saito A, de Strihou CV, Kurokawa K: Glucose degradation product methylglyoxal enhances the production of vascular endothelial growth factor in peritoneal cells: role in the functional and morphological alterations of peritoneal membranes in peritoneal dialysis. FEBS Lett 1999;463:260264.

-48 Visser CE, Tekstra J, Brouwer-Steenbergen JJ, Tuk CW, Boorsma DM, Sampat-Sardjoepersad SC, Meijer S, Krediet RT, Beelen RH: Chemokines produced by mesothelial cells: huGRO-alpha, IP-10, MCP-1 and RANTES. Clin Exp Immunol 1998;112:270-275.

49 Pecoits-Filho R, Araujo MRT, Lindholm B, Stenvinkel P, Abensur H, Romao JE, Marcondes M, de Oliveira AHF, Noronha IL: Plasma and dialysate IL- 6 and VEGF concentrations are associated with high peritoneal solute transport rate. Nephrol Dial Transplant 2002;17:1480-1486.
50 Aroeira LS, Aguilera A, Selgas R, RamirezHuesca M, Perez-Lozano ML, Cirugeda A, Bajo MA, Del PG, Sanchez-Tomero JA, Jimenez-Heffernan JA, Lopez-Cabrera M: Mesenchymal conversion of mesothelial cells as a mechanism responsible for high solute transport rate in peritoneal dialysis: role of vascular endothelial growth factor. Am J Kidney Dis 2005;46:938-948.

51 Duman S: The renin-angiotensin system and peritoneal dialysis. Perit Dial Int 2004;24: 5-9.

52 Aroeira LS, Lara-Pezzi E, Loureiro J, Aguilera A, Ramirez-Huesca M, Gonzalez-Mateo G, Perez-Lozano ML, bar-Vizcaino P, Bajo MA, Del PG, Sanchez-Tomero JA, JimenezHeffernan JA, Selgas R, Lopez-Cabrera M: Cyclooxygenase- 2 mediates dialysate-induced alterations of the peritoneal membrane. J Am Soc Nephrol 2009;20:582-592.

53 Iniguez MA, Rodriguez A, Volpert OV, Fresno M, Redondo JM: Cyclooxygenase-2: a therapeutic target in angiogenesis. Trends Mol Med 2003;9:73-78.

54 Fabbrini P, Schilte MN, Zareie M, ter Wee $\mathrm{PM}$, Keuning ED, Beelen RH, van den BJ: Celecoxib treatment reduces peritoneal fibrosis and angiogenesis and prevents ultrafiltration failure in experimental peritoneal dialysis. Nephrol Dial Transplant 2009;24:36693676.

-55 Tapiawala SN, Bargman JM, Oreopoulos DG, Simons M: Prolonged use of the tyrosine kinase inhibitor in a peritoneal dialysis patient with metastatic renal cell carcinoma: possible beneficial effects on peritoneal membrane and peritonitis rates. Int Urol Nephrol 2009;41:431-434.

56 DePrimo SE, Bello CL, Smeraglia J, Baum CM, Spinella D, Rini BI, Michaelson MD, Motzer RJ: Circulating protein biomarkers of pharmacodynamic activity of sunitinib in patients with metastatic renal cell carcinoma: modulation of VEGF and VEGF-related proteins. J Transl Med 2007;5:32.

57 Sandoval P, Loureiro J, Gonzalez-Mateo G, Perez-Lozano ML, Maldonado-Rodriguez A, Sanchez-Tomero JA, Mendoza L, Santamaria B, Ortiz A, Ruiz-Ortega M, Selgas R, Martin P, Sanchez-Madrid F, Aguilera A, Lopez-Cabrera M: PPAR-gamma agonist rosiglitazone protects peritoneal membrane from dialysis fluid-induced damage. Lab Invest 2010;90:1517-1532.

58 Singh S, Loke YK, Furberg CD: Long-term risk of cardiovascular events with rosiglitazone - A meta-analysis. JAMA2007;298: 1189-1195.

59 Schilte MN, Celie JW, Wee PM, Beelen RH, van den Born J: Factors contributing to peritoneal tissue remodeling in peritoneal dialysis. Perit Dial Int 2009;29:605-617. 